\title{
Philip Meyer, the outsider who created Precision Journalism
}

\section{Marília Gehrke}

Mestranda, Universidade Federal do Rio Grande do Sul, Porto Alegre, RS, Brasil

mariliagehrke@gmail.com

\section{Luciana Mielniczuk}

Doutora, Universidade Federal do Rio Grande do Sul, Porto Alegre, RS, Brasil

luciana.mielniczuk@gmail.com

\begin{abstract}
The value of Philip Meyer's trajectory for journalism studies is the main point of this interview. He created the concept called Precision Journalism, which brings journalism close to science through social research methods, and is also the name of a book published for the first time in 1973. Although Precision Journalism doesn't necessarily require the use of computers, Meyer started to work with them before their popularization, during Detroit's riots in 1967, after spending nine months at Harvard University. By using sample in the journalistic narrative, Meyer and Detroit Free Press staff won a Pulitzer Prize one year later. Precision Journalism is a concept still used, but nowadays is more associated to data journalism. In this interview, answered by e-mail, Meyer not only remembers his career and talks about journalism practice, like the use of data, hypothesis and transparency, but also reveals his perceptions about journalism in the future.
\end{abstract}

\section{Keywords}

Philip Meyer. Journalism. Precision Journalism. Data Journalism.

He doesn't consider himself a visionary, but his ideas, especially since the 1960's, have changed the practice of journalism in the world. Philip Meyer is an 86-year-old American journalist with experience in the newsroom as a reporter, editor and correspondent, and as a professor emeritus at the University of North Carolina at Chapel Hill. The title of this interview is inspired by Meyer's autobiography: at the beginning, he claims that to think differently was never a problem in his family, since it was common to be an outsider, which he definitely was. 
During his career as a reporter and correspondent, Meyer spent a period (19661967) as a Nieman Fellow at Harvard University, where he learned quantitative methods in social sciences, which was decisive to the coverage of Detroit's riots in 1967. He was part of Detroit Free Press' staff when got designated to this coverage. In order to offer a detailed narrative about the riot's areas, Meyer proposed a scientific research to identify the rioters' claims. It included a work with hypotheses and the use of computer for sample's statistics tests. All this work was decisive to win the most important journalism award: in 1968, Detroit Free Press staff was the Pulitzer Prize winner of General Local Reporting.

The experience in and outside the newsroom prepared Meyer to one of his greatest contributions in journalism and it is also the reason why he is known in different countries: the book Precision Journalism, first published in 1973. This book is about bringing journalism close to the science path, using social and behavioral science research methods to its practices. Although using a computer is not the main point in Precision Journalism, Meyer is considered the creator of Computer-Assisted Reporting (CAR). This term is still used in journalism, but Meyer himself admits that it doesn't make sense to use it anymore. He exemplifies by claiming that nobody says "telephone-assisted reporting" and explains that his contribution wasn't about the technology used for some purpose, but about the scientific method (MEYER, 1999). In 2005, the National Institute of Computer-Assisted Reporting (Nicar) promoted the first edition of Philip Meyer Award to recognize the use of Precision Journalism, computer-assisted reporting and social science techniques in journalism.

Meanwhile, a term that is being spread all over to word is data journalism, which involves data collecting, analysis and visualization. It comprehends features of Precision Journalism, CAR and Computational Journalism, and it is also about public transparency, including official governments' databases and statistics. Meyer once said that writing well wouldn't be the only demanded attribution for journalists, but also it would be necessary to understand and organize data. By e-mail, Meyer answered questions about his own trajectory and the future of journalism. 
Your contact with scientific methods begun when you were still a reporter, when technology was limited and computers were not that famous. Why were you interested in combine science and journalism and offer something different to the readers?

It was the result of a series of accidents. I went to Detroit in 1967 to help the staff of the Free Press cover that summer's riot. It became apparent that more was going on than could be reported by conventional means, and I had just finished a year at Harvard studying social science research methods. I proposed a survey of residents in the riot area, and the editors found the funding and took me up on it.

\section{What was the most valuable learning as a Nieman fellow in Harvard?}

The single most important thing I learned was that scientific research was something I could do, rather than just observe and report about. The critical step was learning to code in Harvard Data-Text, a higher-level statistical language written for the now-obsolete IBM 7090 mainframe computer. It made statistical analysis available to people who were more interested in words than numbers. That opened my eyes to the power of data analysis. I should have learned that in graduate school (1956-1958), but the computing power that I needed did not exist then.

In Precision Journalism you say a reporter needs to have more than a good writing and tell the truth. It is necessary to filter, organize and interpret the information in a universe full of data. It still makes sense, doesn't it? Should journalists program computers as well? Or at least know the process?

Yes. Today's generation of journalists, even more than mine, needs to understand and appreciate the importance of hands-on computer experience. We are locked in a battle with less reputable suppliers of information, and truth made visible is our weapon.

Three years had passed between the first version and the effective publication of Precision Journalism. Why did you insist in publishing the book?

I knew there was a market for it, but it took two years to find a publisher who agreed with me - plus one more year for production and distribution using 20th century publishing technology. I thought it was worth the wait. Details of that struggle are in my self-published autobiography, Paper route: finding my way to precision journalism (2012). 
If Precision Journalism was written today, what would you change considering nowadays resources? Would it still be the application of social and behavioral Science research methods to the practice of journalism?

It would. The computer was just a tool to get the investigation done at journalistic speed. My contribution was demonstrating the value of scientific method for analysis and fact-finding.

If Detroit riots were today, how would be the journalistic coverage? Would you still try to identify a hypothesis and prove it with some research? Would this coverage also win a Pulitzer Prize?

Paul Lewis of the Guardian, working with the London School of Economics did just that to cover the London riots of 2011. The Pulitzer Prize? I don't know. My contribution to the one awarded to the Free Press staff was just another happy accident.

What subjects did you teach in Chapel Hill? You are a professor emeritus from this university since 2008, right? How does it work? Do you still talk to the students or to other professors?

Yes. I taught research methods, advanced reporting, and media ethics, plus some seminars on special topics. I cut back to half-time teaching in 2005 and retired in 2008. I live close to campus and stay in touch with former colleagues. My last formal lecture was in Vienna in 2014.

What are the differences between the power of a reporter and the power of a professor?

Time and scale are the only differences. Both are in the business of discovering and imparting the truth. A professor has more freedom to do it his or her own way, and that is why I made the transition after I turned 50.

Precision Journalism and CAR are key-concepts in what we know today as data journalism. You were the beginner and we always talk about you in our studies. How can the practice of these concepts in journalism offer the public some knowledge?

Data journalism is still evolving as a concept. It can include curation as well as analysis and reporting. The Miami Herald, many years ago, organized local property tax records into a user-friendly database that citizens could employ to compare their home valuations to those of their neighbors. Data journalism can also mean using data collected 
for a different purpose to test a newsworthy hypothesis, but there will always be cases where journalists need to collect their own data.

How to build a consistent and qualified content in journalism?

First, find the right business model. The problem today is that falsehood is as easy to sell as truth. At my old outfit, Knight-Ridder Newspapers, we tried to position our product as "influence." We created social influence, which was not for sale, and commercial influence, which we sold as advertising. The more we were respected for truth telling, the more the advertising was worth. That business model was wrecked by the low variable costs of the Internet, and we need to invent a new model. Some of the most promising efforts today are coming from non-profit organizations such as ProPublica and the Center for Public Integrity.

Is journalism closer to the science nowadays? Does the quality of journalism depend on being in touch with science?

Journalism today is in trouble because the traditional means of funding it are falling apart. See my 2009 book The Vanishing Newspaper. Thomas Jefferson once said that he could envision newspapers without democracy but not democracy without newspapers. We're still trying to figure out how to update that observation in a world with Twitter and Facebook. Discovering the truth is one problem. Packaging it and selling it is quite another in a world where attention is the scarce good.

Is it possible to find a balance between speed and precision in journalism? Does the internet help or mess everything up?

The balance is essential. The internet, if used carefully, can help in the same way a library helps, but one must know which sites are well curated, which are carelessly managed, and whose are deliberately designed to deceive. We shall always need crosschecking. A fictional newspaper editor in a 1950s movie wore both belt and suspenders as a reminder to "check and double-check." That need will always exist.

There isn't a tradition, at least in Brazil, about the quantitative methods' use in daily journalism and in universities studies. But we talk a lot about not depending on official sources and the necessity of using databases. Do you consider yourself a visionary by realizing the 
importance of quantitative methods before the internet and the popularization of the computers use?

No. I was simply making use of new tools when I found out about them. Does anybody remember the first reporter to use a telephone? Was that person called a "telephone-assisted reporter?" I like to think of my contribution not as a computer-assisted reporting, but as the application of scientific method: hypothesis testing through such tools as sampling, significance testing, correlation analysis, and field experiments. Those tools were available long before computers. The computer is just a machine that makes scientific method more accessible. The internet is another tool, and its applications are still being worked out - for better or for worse.

Some governments are adopting open source politics and offering databases in their websites. Do the journalists use these databases properly?

I don't know. Somebody ought to investigate.

Is it more complex to interview human or non-human sources (like numbers, tables, documents)?

The advantage of non-human sources you cite is that they hold still. The act of observation or measurement does not change them. One of the ironies of public opinion research is that the act of asking a member of the public a question can render him or her non-representative. George Gallup found this out decades ago when he noticed in panel studies that persons who were interviewed about the election were more likely to vote than those who did not have that experience. There is a wonderful book about ways to deal with this phenomenon: Unobtrusive measures by Eugene Webb and Donald Campbell (2000).

What do you think about the combination of data and user participation in journalistic processes? Some media companies are betting on a movement named crowdsourcing, which allows people to analyze documents and numbers, helping to extract data.

Steve Doig pioneered in this concept when he was at the Miami Herald. He created a system that allowed readers to search a database and compare their neighbors' property tax assessments to their own. Local taxing jurisdictions provide this accessibility routinely now, but when the Herald did so, it was a radical idea. I am not sure where this is going to lead, but letting the audience participate in data analysis sounds like an excellent idea. 
When we think of hypothesis in journalism are we necessarily talking about statistics? Or is it possible to work with hypothesis every day, in every coverage?

We all work with hypotheses in everyday life, but without thinking about it very much. Hypothesis formulation is part of the scientific process called "operationalization." It means asking a question of nature in a way that we will not be fooled by the answer. We confirm or reject a hypothesis by tracking its consequences to something that we can confirm or reject by observation. Statistics are useful if we want to draw inferences from a sample of all the possible observations and/or if we need to evaluate an observation by comparing it with what we would expect from mere chance.

Does journalism have enough transparency? Or should journalists show the readers/users the methods used in news? Should they act more clearly?

It is important for journalists to gain the trust of their readers. Citing sources is one way. Using anonymous sources undermines trust. In my best work as a reporter, I used anonymous sources to guide me to documents or other sources that could be named. This disclosure makes the findings replicable. The best journalism describes its methods with such clarity and precision that the reader is convinced that he or she could follow the same procedure and reach the same conclusions.

There is a phenomenon named "fact-checking" which journalists verify quotes and numbers spread by politicians and other kind of authorities. In Brazil this work is executed by news agencies that call themselves independents. Isn't it ironic that a basic and important value in journalism has become some kind of business?

Yes. There is a world-wide cultural phenomenon called post-modernism that sees truth-seeking as constraining instead of liberating. It denies the existence of objective reality and holds that every observation is open to interpretation depending on the observer's needs and circumstances. We are seeing a lot of this attitude in the USA these days, and, as a consequence, institutions dedicated to fact-checking are in great demand. I wish them well.

How do you see the future of journalism? Is this future in databases and statistics?

My main concern for the future is how we will pay for journalism. The advertisersupported model has been broken by the Internet. Charitable organizations are picking up 
some of the slack. We need to find new ways to monetize truth-telling. That will be more important than finding new methods.

In your texts, you mentioned the book Interpretative reporting, by Curtis MacDougall (1954). Does this content still make sense for journalists nowadays? Do you recommend?

Yes, and when my granddaughter majored in journalism, I gave her my copy of MacDougall's second edition. Readers deserve not just the facts, but the truth about the facts.

You mentioned a movie about a character who wore suspenders. Do you have any suggestions about movies to inspire journalists?

It was belt and suspenders, signifying the importance of redundancy in factchecking. My favorite movie is from the same period (1952): Deadline USA, with Humphrey Bogart as editor of a dying newspaper going after one last investigative story. I also like the 1976 film All the president's men (1976), about the Watergate investigation by the Washington Post.

What you would say or what tips would you give to young journalists who want to work with data journalism or quantitative and social methods to improve journalism? How to think outside the box like you did?

Be lucky. Don't be afraid to be different. Wear belt and suspenders.

\section{References}

ALL the President's Men. Produced by Walter Coblenz. Washington: Wildwood Enterprises, 1976. 1 DVD.

DEADLINE U.S.A. Produced by Sol C. Siegel. New York: 20th Century Fox, 1952. 1 DVD.

MACDOUGALL, Curtis D. Interpretative reporting. New York: MacMillan, 1954.

MEYER, Philip. Paper route: finding my way to precision journalism. Bloomington: iUniverse, 2012.

MEYER, Philip. Precision journalism. Lanham: Rowman \& Littlefield Publishers, 2002. 
MEYER, Philip. The future of CAR: declare victory and get out. In: PAUL, Nora (Org.). When nerds and words collide: reflections on the development of Computer Assisted Reporting. Saint Petersburg: Poynter Institute, 1999. p. 4-5.

MEYER, Philip. The vanishing newspaper: saving journalism in the information age. 2nd ed. Columbia: University of Missouri, 2009.

WEBB, Eugene et al. Unobtrusive measures. Thousand Oaks: Sage Publications, 2000.

\section{Philip Meyer, el outsider que creó el Periodismo de Precisión}

\section{Resumen}

La importancia de la trayectoria de Philip Meyer para los estudios de periodismo es el tema principal de esta entrevista. Él es el creador del Periodismo de Precisión. Un concepto que acerca el periodismo y la ciencia a través de métodos científicos sociales y que da nombre a uno de sus libros publicado por primera vez en 1973. Aunque el Periodismo de Precisión no exigía necesariamente el uso de computadoras, Meyer trabajó con máquinas antes de su popularización, en la cobertura de las manifestaciones de Detroit, en 1967, después de haber estado nueve meses en la Universidad de Harvard. Incorporando muestras en la narrativa periodística, Meyer y el equipo del periódico Detroit Free Press recibieron el Premio Pulitzer del año siguiente. El concepto Periodismo de Precisión todavía es usado actualmente, pero está más asociado al Periodismo de Datos. En esta entrevista, contestada por e-mail, Meyer recuerda aspectos de su trayectoria profesional y comenta sobre la práctica periodística, desde el uso de datos, la transparencia y la hipótesis. Además, revela sus percepciones sobre el futuro del periodismo.

\section{Palavras clave}

Philip Meyer. Periodismo. Periodismo de Precisión. Periodismo de datos. 


\section{Philip Meyer, o outsider que criou o Jornalismo de Precisão}

\section{Resumo}

A importância da trajetória de Philip Meyer para os estudos de jornalismo é o ponto principal desta entrevista. Ele é o criador do Jornalismo de Precisão, conceito que aproxima o jornalismo da ciência por meio de métodos científicos sociais, e que, também, dá nome a um de seus livros, publicado pela primeira vez em 1973. Ainda que o Jornalismo de Precisão não demande, necessariamente, o uso de computadores, Meyer começou a trabalhar com as máquinas antes de sua popularização, nos protestos de Detroit, em 1967, depois de passar nove meses na Universidade de Harvard. Utilizando amostra na narrativa jornalística, Meyer e a equipe do jornal Detroit Free Press receberam um Prêmio Pulitzer um ano depois. O Jornalismo de Precisão ainda é um conceito utilizado, mas hoje mais associado ao jornalismo de dados. Nessa entrevista, respondida por email, Meyer não só relembra aspectos de sua carreira e fala sobre a prática jornalística, como o uso de dados, transparência e hipótese, bem como revela suas percepções sobre o futuro do jornalismo.

\section{Palavras-chave}

Philip Meyer. Jornalismo. Jornalismo de Precisão. Jornalismo de dados.

Recebido em 30/03/2017

Aceito em 03/04/2017 